\title{
The Role of Teachers in Drug Abuse Prevention in Schools
}

Ciptro Handrianto, Ahmad Jazimin Jusoh, Pauline Goh Swee Choo, Nazre Abdul Rashid, M. Arinal Rahman

To Link this Article: http://dx.doi.org/10.6007/IJARBSS/v10-i11/8131

DOI:10.6007/IJARBSS/v10-i11/8131

Received: 04 September 2020, Revised: 27 September 2020, Accepted: 19 October 2020

Published Online: 20 November 2020

In-Text Citation: (Handrianto, et. al., 2020)

To Cite this Article: Handrianto, C., Jusoh, A. J., Choo, P. G. S., Abdul Rashid, N., Rahman, M. A. (2020). The Role of Teachers in Drug Abuse Prevention in Schools. International Journal of Academic Research in Business and Social Sciences. 10(11), 708-716.

\section{Copyright: (c) 2020 The Author(s)}

Published by Human Resource Management Academic Research Society (www.hrmars.com)

This article is published under the Creative Commons Attribution (CC BY 4.0) license. Anyone may reproduce, distribute, translate and create derivative works of this article (for both commercial and non-commercial purposes), subject to full attribution to the original publication and authors. The full terms of this license may be seen at: http://creativecommons.org/licences/by/4.0/legalcode

\section{Vol. 10, No. 11, 2020, Pg. 708 - 716}

Full Terms \& Conditions of access and use can be found at http://hrmars.com/index.php/pages/detail/publication-ethics 


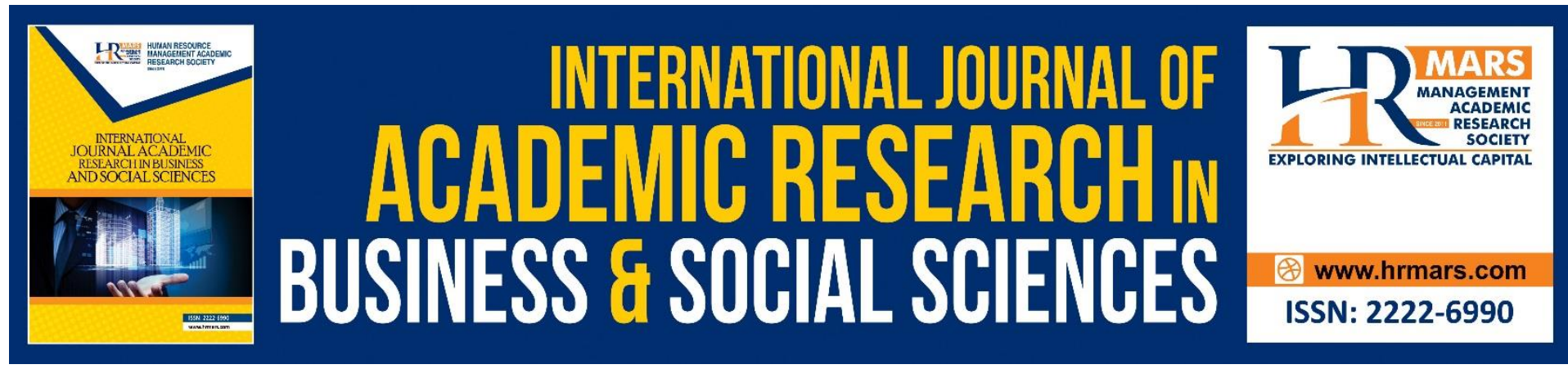

\title{
The Role of Teachers in Drug Abuse Prevention in Schools
}

\author{
Ciptro Handrianto ${ }^{1}$, Ahmad Jazimin Jusoh¹, Pauline Goh Swee \\ Choo $^{1}$, Nazre Abdul Rashid ${ }^{1}$, M. Arinal Rahman ${ }^{2}$ \\ ${ }^{1}$ Sultan Idris Education University, Malaysia, ${ }^{2}$ UIN Antasari Banjarmasin, Indonesia \\ Email: handriantociptro@gmail.com
}

\begin{abstract}
This exploratory study is an attempt to investigate the work-the role of teachers in drug abuse prevention in schools. The drug is one of the forbidden item consumed by human. Nevertheless, students who are still too young got exposed to the drug. Having a good teacher will greatly prevent the students to abuse the drug. Teachers' roles have resulted as the key factor for the prevention of the consumption of drug because students spend most of their quality time at school. This paper is intended to study the possibility of the existence of the role of teachers in drug prevention in schools in Malaysia. A mixed methods research design shall be deployed for the study. A conceptual framework with factors such as teaching competency, teachers' self-efficacy, the teaching-learning process in the classroom, and school environment.
\end{abstract}

Keywords: Drug Abuse Prevention, Teachers' Role, Teaching Competency, Teachers' SelfEfficacy, Learning Process, School Environment

\section{Introduction}

For several decades, drug prevention research has attempted to understand the causes and consequences of teachers' roles (Djigic \& Stojiljkovic, 2011; Ofsted, 2010; Formby, Coldwell, Stiell, Demack, Stevens, \& Shipton, 2011). Studies have shown that a school which values teachers' roles and recognizes the importance of school environment stands to win in terms of students' morale and commitment to not use the drug (Moreira, Vóvio, \& Micheli, 2015; Chan, Sidhu, Lim, \& Wee, 2016; Razali \& Madon, 2016). Yet many schools and teachers pay scant regard to try to prevent the students from a drug (NADA, 2017; Pereira \& Sanchez, 2018).

Based on the data from National Anti Drug Agency (AADK, 2016), there were 178 areas across Malaysia identified high-risk areas for drug abuse, namely in Perak (30), Johor (23), Negeri Sembilan (16), Selangor (15), Kedah (13), Kelantan (13), Pahang (12), Pulau Pinang (11), WP Kuala Lumpur (10), Terengganu (10), Malaka (7), Sarawak (7) Sabah (7) and Perlis (4). The AADK also identified that 1,017 (42\%) of the 2,408 secondary schools in Malaysia were identified as drug-schools at risk. There were 913,576 (41\%) of 2,188,525 secondary school students from all over Malaysia identified as having a drug or tested positive for urine. Most of those involved were fourth and fifth-grade students. It is recognised that school are noted 
for having characteristics known to be detrimental to students' life, such as make drug transaction in their school (Tam \& Foo, 2012).

These detrimental cases are considered to be greatly linked with the teachers-students relationship within the schools. Hence schools have come up with strategies such as providing information and giving attention to students (Adhani \& Anshori, 2018), interactive teaching (Giles, Pankratz, Ringwalt, Hansen, Dusenbury, \& Jackson-Newsom, 2010), and handling school's Drug Prevention Education (PPDa) program (Sukor\&Hussin, 2019). Therefore, the objective of this study were:

- This study will explore the literatures related to the roles of teachers in preventing drug abuse.

- This study will explore the literatures related to effect of the teachers' role towards the students.

\section{Review of Literature}

Students or young generations are high risks to be involved in drug abuse. In Malaysia, the drug was named as the nation's number one enemy in 1893 and ever since then, the fight against drugs was conducted aggressively by widening the awareness scope at all age level. Though many studies have evolved in the concept of teachers' roles in drug prevention often it is also quoted as school roles in drug preventions (Sharma, Arora, Singh, Singh, and Kaur, 2017). School environment affects teachers ' perceptions of the building, administrative staff, students, school facilities, and other teachers. The collaboration of school components is needed in drug prevention at school. Teachers work together with all school members and parents to create a school climate of free drug school. Positive school environment brings satisfaction to the teachers to improve their roles in drug abuse prevention at school.

The evolution of literature studies in drug prevention by the teachers in several countries can be seen as below:

Table 1. Literature Studies in Drug Prevention by The Teachers in Several Countries

\begin{tabular}{|c|c|c|l|l|}
\hline S.No & Year & Country & \multicolumn{1}{|c|}{ Design } & \multicolumn{1}{|c|}{ Roles of Teachers } \\
\hline 1 & 2010 & USA & $\begin{array}{l}\text { Quantitative } \\
\text { study }\end{array}$ & Interactive teaching. \\
\hline 2 & 2013 & USA & $\begin{array}{l}\text { Qualitative } \\
\text { approach }\end{array}$ & $\begin{array}{l}\text { Altering the delivery of the lesson, } \\
\text { changing the content of the lesson, } \\
\text { assigning small group activities to } \\
\text { students, responding to constraints (time, } \\
\text { institutional, personal, and technical), and } \\
\text { responding to student needs (students' } \\
\text { abilities to process curriculum content, to } \\
\text { enhance student engagement with the } \\
\text { material. }\end{array}$ \\
\hline 3 & 2014 & Australia & $\begin{array}{l}\text { Experimental } \\
\text { research }\end{array}$ & $\begin{array}{l}\text { Reinforcing the learning outcomes } \\
\text { outlined in the cartoons allowing } \\
\text { interactive communication between } \\
\text { students, and providing access to all } \\
\text { program materials including an outline of }\end{array}$ \\
\hline
\end{tabular}




\begin{tabular}{|c|c|c|c|c|}
\hline & & & & $\begin{array}{l}\text { activities, implementation guidelines, links } \\
\text { to the education. syllabus and summaries } \\
\text { for each lesson. }\end{array}$ \\
\hline 4 & 2015 & USA & $\begin{array}{l}\text { Qualitative } \\
\text { design }\end{array}$ & $\begin{array}{l}\text { Increase narrative quality, student } \\
\text { engagement, and develop a prevention } \\
\text { curriculum. }\end{array}$ \\
\hline 5 & 2015 & Suriname & $\begin{array}{l}\text { Mixed } \\
\text { methods }\end{array}$ & $\begin{array}{l}\text { Implementing McGuire's persuasion } \\
\text { communication model and developing } \\
\text { learning material. }\end{array}$ \\
\hline 6 & 2016 & Russia & $\begin{array}{l}\text { Theoretical } \\
\text { analysis of } \\
\text { empirical data }\end{array}$ & $\begin{array}{l}\text { Giving positive motivation, training } \\
\text { courses, workshops, active cooperation of } \\
\text { all agencies. }\end{array}$ \\
\hline 7 & 2016 & Brazil & $\begin{array}{l}\text { Mixed } \\
\text { methods }\end{array}$ & $\begin{array}{l}\text { Managing time necessary to plan the } \\
\text { lessons and implementing the activities. }\end{array}$ \\
\hline 8 & 2017 & Brazil & $\begin{array}{l}\text { Mixed } \\
\text { research }\end{array}$ & $\begin{array}{l}\text { Interactive learning and drug prevention } \\
\text { training. }\end{array}$ \\
\hline 9 & 2017 & India & $\begin{array}{l}\text { Quantitative } \\
\text { approach }\end{array}$ & $\begin{array}{l}\text { Planning prevention and rehabilitation } \\
\text { activities for drug abuse. }\end{array}$ \\
\hline 10 & 2018 & Indonesia & $\begin{array}{l}\text { Combination } \\
\text { of qualitative } \\
\text { and } \\
\text { quantitative } \\
\text { approaches }\end{array}$ & $\begin{array}{l}\text { Providing information and giving attention } \\
\text { to students. }\end{array}$ \\
\hline 11 & 2018 & Venezuela & $\begin{array}{l}\text { Experimental } \\
\text { research }\end{array}$ & $\begin{array}{l}\text { Developing a relationship with the } \\
\text { community, parental involvement, and } \\
\text { giving awareness to the students. }\end{array}$ \\
\hline 12 & 2018 & USA & $\begin{array}{l}\text { Qualitative } \\
\text { study }\end{array}$ & $\begin{array}{l}\text { Implementation culturally specific content } \\
\text { in the curriculum's structure. }\end{array}$ \\
\hline 13 & 2018 & Iran & $\begin{array}{l}\text { Experimental } \\
\text { research }\end{array}$ & $\begin{array}{l}\text { Delivering lessons and materials based on } \\
\text { the developmental, etiologic factors and } \\
\text { social stimulation. }\end{array}$ \\
\hline 14 & 2018 & Australia & $\begin{array}{l}\text { Cluster } \\
\text { randomised } \\
\text { controlled trial } \\
\end{array}$ & $\begin{array}{l}\text { Supervision classroom setting, preparing } \\
\text { online worksheets, discussion, and } \\
\text { intervention online cartoon lessons. }\end{array}$ \\
\hline 15 & 2018 & Brazil & $\begin{array}{l}\text { Quantitative } \\
\text { method }\end{array}$ & $\begin{array}{l}\text { Belonging public school network, } \\
\text { developing } \\
\text { extracurricular activities, and participating } \\
\text { in training courses on drugs. }\end{array}$ \\
\hline 16 & 2019 & Indonesia & $\begin{array}{l}\text { Experimental } \\
\text { study }\end{array}$ & $\begin{array}{l}\text { Strengthening positive belief, improving } \\
\text { knowledge, and preparing learning } \\
\text { materials. }\end{array}$ \\
\hline 17 & 2019 & Indonesia & $\begin{array}{l}\text { Qualitative } \\
\text { approach }\end{array}$ & $\begin{array}{l}\text { Personal approach mechanism, enforcing } \\
\text { action, serving, and empowering } \\
\text { community. }\end{array}$ \\
\hline 18 & 2019 & UK & $\begin{array}{l}\text { Mixed } \\
\text { methods }\end{array}$ & $\begin{array}{l}\text { Improving teaching performance, paying } \\
\text { attention, which contributes to }\end{array}$ \\
\hline
\end{tabular}




\begin{tabular}{|c|c|l|l|l|}
\hline & & & $\begin{array}{l}\text { mindfulness related to topics being } \\
\text { presented. }\end{array}$ \\
\hline 19 & 2019 & Brazil & $\begin{array}{l}\text { Secondary } \\
\text { analysis of a } \\
\text { cluster } \\
\text { randomized } \\
\text { controlled trial }\end{array}$ & $\begin{array}{l}\text { Supervise coaches in training and } \\
\text { managing class in implanting the program. }\end{array}$ \\
\hline
\end{tabular}

Table 1 showed that there are efforts have been made to comprehend the concepts, conflict and enrichment together, so an integrated framework is required to understand the concept of teachers' role and drug prevention in totality. However, research on the teachers' roles in drug prevention has not been taken up greatly in the Malaysian context, there is much space that has not been explored. The following table enlists the some studies that evolved around teachers' roles in the Malaysian context:

Table 2. Teachers' Roles in Drug Prevention in Malaysia

\begin{tabular}{|c|c|c|c|c|}
\hline S.No & Year & Author & Title & Remarks \\
\hline 1 & 2019 & $\begin{array}{l}\text { Sukor and } \\
\text { Hussin }\end{array}$ & $\begin{array}{lrr}\begin{array}{l}\text { Self-Efficacy } \\
\text { Influence }\end{array} & \text { and } & \text { Its } \\
\text { Satisfaction } & & \text { Job } \\
\text { Substance } & & \text { Among } \\
\text { Prevention } & & \text { Abuse } \\
\text { Teachers } & & \text { Program }\end{array}$ & Handling PPDa program. \\
\hline 2 & 2015 & $\begin{array}{l}\text { Fook, Sidhu, } \\
\text { Abd Hamid, } \\
\text { Choo, and } \\
\text { Hoe }\end{array}$ & $\begin{array}{l}\text { Teachers' Perspective on } \\
\text { Challenges of Substance } \\
\text { Abuse Prevention among } \\
\text { Malaysian Secondary } \\
\text { School Students }\end{array}$ & $\begin{array}{l}\text { Highlight supporting from } \\
\text { agencies, financial support, } \\
\text { looking professional advice, } \\
\text { and optimizing rehabilitation } \\
\text { centre. }\end{array}$ \\
\hline
\end{tabular}


Table 2 above showed that, while countries such as Australia, Brazil, India, Indonesia, Iran, United States, United Kingdom, Suriname, Venezuela and Russia have been incorporating teachers' roles in drug prevention for a very long time, this working arrangement is new in the Malaysian school environment. So far, a lot of research in Malaysia has only focused on implementing the drug prevention education program, not on teacher competency and self-efficacy.

\section{Conceptual Framework}

The conceptual framework of the study proposed as below:

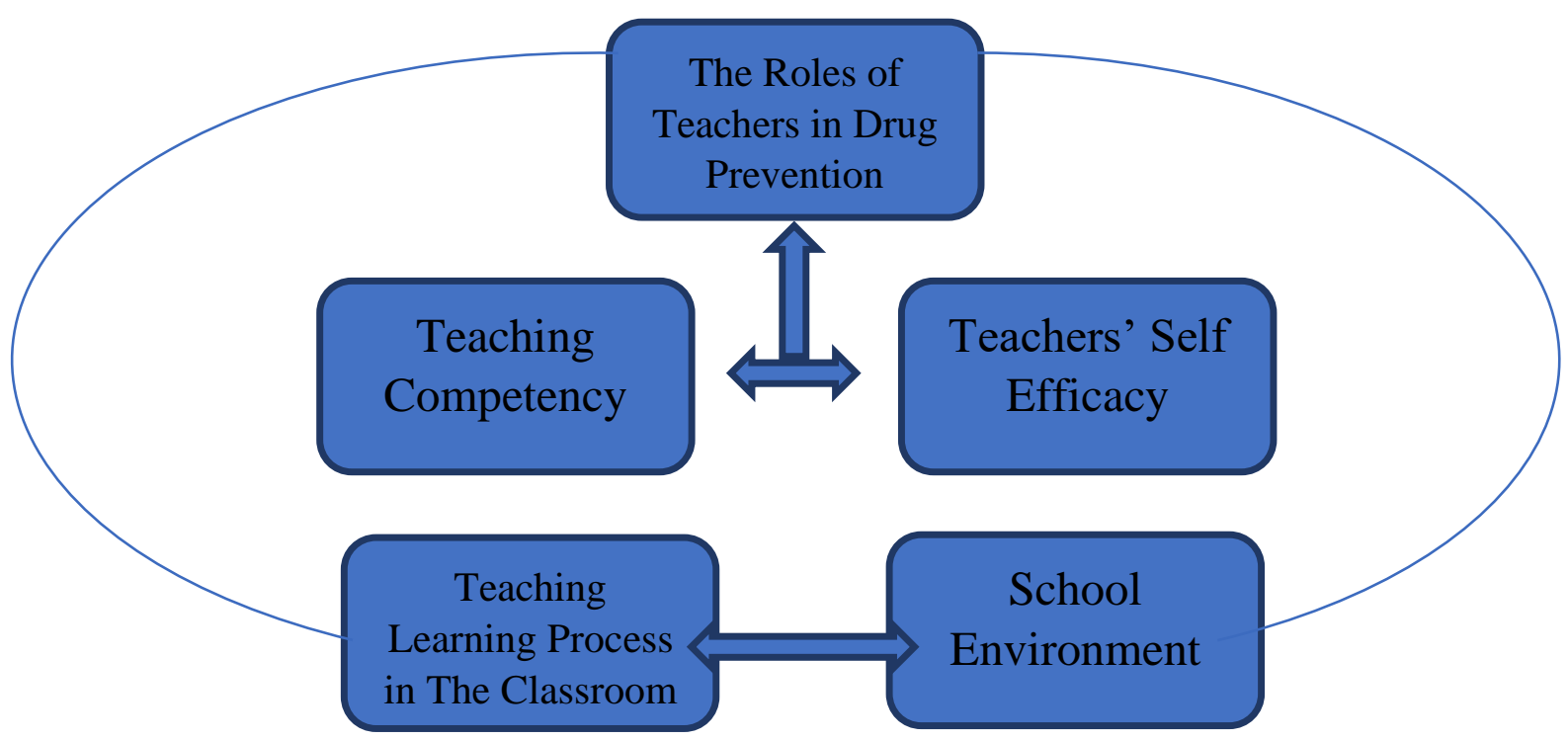

Figure 1. The Roles of Teacher in Drug Prevention in School

The study will show the description and correlation some items such as teaching competency, self-efficacy, a teaching-learning process in the classroom, and school environment. The results will help the government to a deep understanding of making the appropriate decision regarding the drug abuse prevention program in the school's area.

\section{Probable Research Questions}

With the gap being identified as such that such study has not been much analysed in the Malaysian school, therefore giving much room for the following research questions to emerge.

R1. What is the level of teaching competency of teachers in drug abuse prevention in the schools?

Teaching competency of teachers in drug prevention involves subject knowledge as well as pedagogical knowledge of teacher to deliver a message the danger of drug abuse to the students. Teachers should have the ability to elaborate their teaching-learning process to integrate drug prevention program. In this situation, the skill of the teacher is needed to work with students, colleagues, and other professional that are responsible to prevent drug abuse in their school. As a result, the level of teaching competency of teachers in drug abuse prevention is needed to be explored. 
R2. What is the level of teacher's self-efficacy in drug abuse prevention in the schools?

Teachers' self-efficacy is one of the urgent factors to determine the success of drug abuse prevention in school because it has related to teachers 'belief about their capabilities to organize and execute this matter. Drug prevention program in the school depends on how far teachers ' belief inability to plan instruction and accomplish instructional objectives during the teaching-learning process. Teachers with good self-efficacy have a strong commitment to adopt innovation and pay more attention to solve the student's problem in drug abuse. Thus, the level of teacher's self-efficacy in drug abuse is important to be studied.

R3. Is there a relationship between teaching competency and teacher's self-efficacy in drug abuse prevention in schools?

This study specifically makes use of two theories namely, Teaching Competency Theory (Shulman, 1987) and Teachers' Self-Efficacy Theory (Bandura, 1997) because their tenets demonstrated relevant relationship to the parameters measuring effectiveness and objectives of the study.

R4. What are the roles of a teacher in the drug abuse prevention program in school, in terms of:

a. Teaching-learning process in the classroom?

The study by Nozama Bt Mahadi and Bahrin (2015) showed that many samples agree on the teaching and learning of drug abuse in school. It can be said that teaching sessions on drug abuse learning at school show their effectiveness. Teachers and students need to play their part in making the teaching of drug abuse more interesting. Project based learning (Handrianto \& Rahman, 2019) can be implemented in drug education to improve teachersstudents ' connection for problem solving. Hence a thorough study of what teachers do within the teaching-learning process in the classroom need to be identified.

\section{b. School environment?}

The school environment plays a crucial role in the experience of dissatisfaction among public school teachers. When school environment is considered, the study suggests that positive environment and teacher control decrease teacher dissatisfaction; thus teachers who perceive a more positive environment and have more control over their classrooms are more satisfied with their jobs. Having a school leader who communicates with staff members and sets the tone for cooperation, and a shared sense of purpose is critical to teachers' perception of a positive school environment and being satisfied with their jobs (Bogler, 2001). Hence the perceived consequences still need to be explored in the school environment in Malaysia.

\section{Conclusion}

The study is in the very preliminary stage and has to be analysed in the Malaysian teachers. The innate objective of the study is to analyse the roles of teacher and its relevance in the prevention of drug abuse in the Malaysian school. The roles of teachers in drug prevention have been conceptualized in what extent the teaching competency, teachers' self-efficacy, teaching-learning process in the classroom, and school environment.

As the research has demonstrated, clearly, there is need for a greater focus on roles of teachers at school (Sukor \& Hussin, 2019). More research should be done to help learn the effectiveness of teacher's roles in preventing drug abuse among students. Rather than focus on a single role, researchers should restructure other roles that were unrepresentative in 
literatures. For following studies related to drug education, researchers may put attention on correlation or influece all of the roles in preventing drug abuse at Malaysian schools.

\section{Acknowledgement}

We would like to thank the Long Research Grant Scheme (LRGS), Sultan Idris Education University, and The Ministry of Education Malaysia which provide financial support for conducting this research.

\section{References}

AADK. Agensi Anti DadahKebangsaan. (2016). Maklumat Dadah 2016. Retrieved from https://www.adk.gov.my/wpcontent/uploads/BUKUSTATISTIK-2016.pdf.

Adhani, A., \& Anshori, A. (2018). Persuation of Teacher Communication in Preventing the Danger of Drug Abuse on High School Students. Budapest International Research and Critics Institute (BIRCI-Journal): Humanities and Social Sciences, 1(3), 153-159. https://doi.org/10.33258/birci.v1i3.39.g37

Bandura, A. (1997). Self-efficacy: The Exercise of Control. New York: W. H. Freeman and Company.

Bogler, R. (2001). The influence of leadership style on teacher satisfaction. Educational Administration Quarterly, 37, 662-683. doi: 10.5897/IJEAPS12.036

Chan, Y. F., Sidhu, G. K., Lim, P. C., \& Wee, E. H. (2016). Students' Perceptions of Substance Abuse Among Secondary School Students in Malaysia. Pertanika Journal of Social Sciences \& Humanities, 24(2).

https://www.researchgate.net/publication/304843022_Students'_perceptions_of_s ubstance_abuse_among_secondary_school_students_in_Malaysia

Djigic, G., \& Stojiljkovic, S. (2011). Classroom management styles, classroom climate and school achievement. Procedia-Social and Behavioral Sciences, 29, 819-828. doi: 10.1016/j.sbspro.2011.11.310

Giles, S. M., Pankratz, M. M., Ringwalt, C., Hansen, W. B., Dusenbury, L., \& Jackson-Newsom, J. (2010). Teachers' delivery skills and substance use prevention program outcomes: The moderating role of students' need for cognition and impulse decision making. Journal of Drug Education, 40(4), 395-410. doi: 10.2190/de.40.4.e

Fook, C. Y., Sidhu, G. K., Abd Hamid, M. Z., Choo, L. P., \& Hoe, W. E. (2015). Teachers' perspective on challenges of substance abuse prevention among malaysian secondary school students. Jurnal Pendidikan Malaysia (Malaysian Journal of Education), 40(1), 21-27. doi: 10.17576/JPEN-2015-4001-04

Formby, E., Coldwell, M., Stiell, B., Demack, S., Stevens, A., Shipton, L. (2011). Personal, Social, Health and Economic (PSHE) Education: A mapping study of the prevalent models of delivery and their effectiveness. Department for Education.

Handrianto, C., \& Rahman, M. A. (2019). Project based learning: a review of literature on its outcomes and implementation issues. LET: Linguistics, Literature and English Teaching Journal, 8(2), 110-129. http://dx.doi.org/10.18592/let.v8i2.2394

Moreira, A., Vóvio, C. L., \& Micheli, D. D. (2015). Drug abuse prevention in school: challenges and possibilities for the role of the educator. Educação e Pesquisa, 41(1), 119-135. https://doi.org/10.1590/S1517-97022015011670

NADA. National Anti Drug Agency. (2017). National Drug Policy Ministry of Home Affairs. Selangor: MHA Press. 
Ofsted. (2010) Personal, Social, Health and Economic Education in Schools. Manchester: Ofsted.

Pereira, A. P. D., \& Sanchez, Z. M. (2018). Drug use prevention: factors associated with program implementation in Brazilian urban schools. BMC public health, 18(1), 334. https://doi.org/10.1186/s12889-018-5242-y

Razali, A., \& Madon, Z. (2016). Issues and challenges of drug addiction among students in Malaysia. Advances in Social Sciences Research Journal, 3(8). doi: 10.14738/assrj.38.2126

Sharma, B., Arora, A., Singh, K., Singh, H., \& Kaur, P. (2017). Drug abuse: Uncovering the burden in rural Punjab. Journal of family medicine and primary care, 6(3), 558. doi: 10.4103/2249-4863.222037

Shulman, L. S. (1987). Knowledge and teaching: foundations of the new reform. Harvard Educational Review, 57(1), 122. https://doi.org/10.17763/haer.57.1.j463w79r56455411

Sukor, N. M., \& Hussin, S. Z. (2019). Self-efficacy and its influence on job satisfaction among substance abuse prevention program teachers. AL-'ABQARI: Journal of Islamic Social Sciences and Humanities, 36-45. https://doi.org/10.33102/abqari.vol21no1.225

Tam, C. L., \& Foo, Y. C. (2012). Contributory factors of drug abuse and the accessibility of drugs. International Journal of Collaborative Research on Internal Medicine \& Public Health, 4(9),16-21.

https://www.researchgate.net/publication/289563485_Contributory_Factors_of_Dr ug_Abuse_and_the_Accessibility_of_Drugs 